\title{
Experimental Study to Remediate Acid Fuchsin Dye Using Laccase-Modified Zeolite from Aqueous Solutions
}

\author{
Ekrem Kalkan ${ }^{1 *}$, Hayrunnisa Nadaroglu², Neslihan Celebi', \\ Hulya Celik ${ }^{4}$, Esen Tasgin ${ }^{5}$ \\ 'Geological Engineering Department, Oltu Earth Sciences Faculty, \\ Ataturk University, 25400 Oltu-Erzurum, Turkey \\ ${ }^{2}$ Department of Food Technology, Erzurum Vocational Training School, \\ Ataturk University, 25240 Erzurum, Turkey \\ ${ }^{3}$ Department of Chemical Technology, Erzurum Vocational Training School, \\ Ataturk University, 25240 Erzurum, Turkey \\ ${ }^{4}$ Department of Pharmaceutical Chemistry, Faculty of Pharmacy, \\ Agri Ibrahim Cecen University, 04000 Agri, Turkey \\ 5Faculty of Education, Elementary Science Education, \\ Bayburt University, 69100 Bayburt, Turkey \\ Received: 11 February 2014 \\ Accepted: 28 March 2014
}

\begin{abstract}
This paper studies, the removal of acid fuchsin dye from aqueous solutions using zeolite natural material after its modification with laccase from Russulaceae (Lactarius volemus). Batch adsorption experiments were performed as a function of $\mathrm{pH}$, contact time, temperature, and adsorbent dosage. The optimum results were obtained at $\mathrm{pH} 5$, contact time of $60 \mathrm{~min}$, temperature of $60^{\circ} \mathrm{C}$, and an adsorbent dosage of $1.5 \mathrm{mg} / \mathrm{mL}$. The isotherm studies show that the adsorption experimental data are fitted well by Langmuir isotherm model. The adsorption capacity found is $31 \mathrm{mg} / \mathrm{g}$. The kinetics of AFD adsorption on LMZ is best described with the pseudo-first-order kinetics model. Thermodynamic parameters including Gibbs free energy, enthalpy, and entropy changes indicate that the adsorption of Acid Fuchsin dye onto laccase-modified zeolite is feasible, spontaneous, and exothermic. The results show that laccase-modified zeolite can be used as an alternative lowcost adsorbent for dye removal from aqueous solutions.
\end{abstract}

Keywords: acid fuchsin dye removal, laccase-modified zeolite, adsorption isotherms, adsorption kinetics

\section{Introduction}

The release of colored effluents to the aquatic environment without adequate treatment causes public concern, legislative problems, and is a serious challenge to environ-

*e-mail: ekalkan@atauni.edu.tr mental scientists. Synthetic origin and complex aromatic structures of dyes make them stable and difficult to remove using traditional wastewater treatment technologies $[1,2]$. Since dye compounds are specifically designed to be recalcitrant with poor biodegradability, they are very stable and difficult to degrade by conventional aerobic biological treatments, such as the activated sludge process [4-7]. 
Various physical, chemical, and biological methods, namely adsorption, biosorption, coagulation, precipitation, membrane filtration, solvent extraction, chemical oxidation, and photochemical degradation have been used for the treatment of dye containing wastewater. Among these methods, the adsorption process using low-cost adsorbent materials is proved to be an effective process for color removal from wastewater [8-14].

One type of geological natural materials is zeolite. This material is a naturally occurring framework silicate with a three-dimensional cage structure, and they possess permanent negative charges in their structural frameworks that are balanced by exchangeable cations [15]. The use of zeolites as an adsorbent for removing heavy metal ions from aqueous solution has gained great interest due to its high ion exchange capacity [16]. Large deposits of natural zeolites in many countries provide local industries some promising benefits since they are able to treat wastewater contaminated with heavy metals at low cost [17].

Laccase is an enzyme that has the potential ability of oxidation. It belongs to those enzymes that have innate properties of reactive radical production. There are diverse sources of laccase-producing organisms like bacteria, fungi, and plants. Laccases use oxygen and produce water as a byproduct. They have the ability to detoxify a range of environmental pollutants [18].

This paper describes the use of laccase-modified zeolite (LMZ) for removal of acid fuchsin dye (AFD) from aqueous solutions. The adsorption of AFD has been investigated as a function of contact time, $\mathrm{pH}$, temperature, and adsorbent dose. The AFD has been absorbed by LMZ from AFD-polluted wastewater. Adsorption isotherm, kinetic, and thermodynamic studies have been performed to describe the adsorption process.

\section{Materials}

AFD or 2-amino-5-[(4-amino-3-sulfophenyl)(4-imino3-sulfo-2,5-cyclohexadien-1-ylidene)-methyl]-3-methylbenzenesulfonic acid is an organic dye (C.I. 42685) and has the formula $\mathrm{C}_{20} \mathrm{H}_{17} \mathrm{~N}_{3} \mathrm{Na}_{2} \mathrm{O}_{9} \mathrm{~S}_{3}$. AFD, also called Acid Violet 19 or Fuchsin Acid or Rubin S, is widely used for staining procedures [19] and other purposes [20]. Its structure is given in Fig. 1.

The zeolite samples were collected from the open-pit mine in the Gördes (Manisa) region of West Anatolia.<smiles>Cc1cc(C(=C2C=CC(=N)C(S(=O)(=O)O)=C2)c2ccc(N)c(S(=O)(=O)O[Na])c2)cc(S(=O)(=O)O[Na])c1N</smiles>

Fig. 1. Chemical structure of AFD.
The zeolite material has mineralogical content, mainly clinoptilolite (85\%) and other components, including feldspar (10\%) and clay (5\%). Its density is $2.25 \mathrm{~g} / \mathrm{cm}^{3}$ and surface area is $40.80 \mathrm{~m}^{2} / \mathrm{g}$. The reason for selecting zeolite as an adsorbent is its relatively moderate surface area, and exceptionally high and selective ion-exchange capacity [21].

Lactarius volemus (20 g) were ground in liquid $\mathrm{N}_{2}$ and then homogenized in a blender with $50 \mathrm{~mL}$ of $1 \mathrm{M} \mathrm{KCl}$ by shaking, and centrifuged at $5000 \times \mathrm{g}$ for $60 \mathrm{~min}$. The homogenates were centrifuged and precipitates were removed. For the purification of the laccase enzyme the following procedure was implemented [22]. Laccase was purified from the supernatant in two steps. Firstly, it was partially purified by precipitation \% in $\left(\mathrm{NH}_{4}\right)_{2} \mathrm{SO}_{4}$. Secondly, ion exchange chromatography on DEAE-sephadex was used. The collapse of $\left(\mathrm{NH}_{4}\right)_{2} \mathrm{SO}_{4}$ was done from $0 \%$ to $90 \%$ in supernatant with the internals of 0-10, 10-20, 20-30, 3040, 40-50, 50-60, 60-70, 70-80, and 80-90. Significant activity was not observed below the range $0-40 \%$ $\left(\mathrm{NH}_{4}\right)_{2} \mathrm{SO}_{4}$. The majority of activity was found in the 40$60 \%$ precipitate. Solid $\left(\mathrm{NH}_{4}\right)_{2} \mathrm{SO}_{4}$ was added to the supernatant to increase the concentration of $\left(\mathrm{NH}_{4}\right)_{2} \mathrm{SO}_{4}$ from $40 \%$ to $60 \%$. After mixing in an ice-bath for $1 \mathrm{~h}$ with magnetic stirring, it was centrifuged $(10,000 \times \mathrm{g}, 30 \mathrm{~min}$, and $4^{\circ} \mathrm{C}$ ). The supernatant was discarded and the precipitate was dissolved in $0.01 \mathrm{M}$ acetate buffer ( $\mathrm{pH}$ 5.0) and dialyzed against the same buffer [22].

\section{Experimental Procedure}

\section{Material Characterization}

Fourier Transform Infrared Spectroscopy (FTIR) analyses were carried out to identify functional groups and molecular structure. FTIR spectra were recorded on the on Perkin-a Perkin-Elmer GX2000 FTIR spectrometer. The spectrum of the adsorbent was measured within the range of $4000-700 \mathrm{~cm}^{-1}$ wave numbers. The scanning electron microscope (SEM) was used to examine the surface of the adsorbent. Images of native adsorbent and metal-loaded adsorbent were magnified 5000 times by SEM modeled JEOL JSM-6400 SEM. Before SEM examinations, the sample surfaces were coated with a thin layer $(20 \mathrm{~nm})$ of gold to obtain a conductive surface and to avoid electrostatic charging during examination. The same machine was also used for the energy-dispersive X-ray (EDX) spectra analysis to know the elemental composition of the zeolite.

\section{Adsorption Procedure}

The crushed zeolite was thoroughly washed with distilled water until it became neutral. The suspension was wet sieved through a 200-mesh screen. A little amount of the suspension remained on the sieve and was discarded. The solid fraction was washed five times with distilled water following the sequence of mixing, settling, and decanting. 
The last suspension was filtered, and the residual solid was then dried at $105^{\circ} \mathrm{C}$, ground in a mortar, and sieved through a 200-mesh sieve. $1 \mathrm{~g}$ of zeolite sample was shaken with 10 $\mathrm{mL}, 10^{8} \mathrm{CFU} / \mathrm{mL}$ laccase from Lactarius volemus solution for approximately $1 \mathrm{~h}$, and then the separated particles were stored. The laccase from Lactarius volemus modified-zeolite was used for the study of AFD removal from aqueous solution.

Synthetic wastewater was prepared by dissolving AFD. A $10 \mathrm{~mL}$ sample solution was pipetted into a $100 \mathrm{~mL}$ Erlenmeyer flask, and $5 \mathrm{~mL} 0.001 \mathrm{M}$ dithizone was added as a complexion agent. The $\mathrm{pH}$ was adjusted to 7 (optimum value) with $0.001 \mathrm{M} \mathrm{NaOH}$ or $0.001 \mathrm{M} \mathrm{HCl}$. The aqueous phase was diluted to $40 \mathrm{~mL}$. The amount of $0.15 \mathrm{~g}$ naphthalene was added as a solid solvent. Then this solution was heated in a water bath to about $85^{\circ} \mathrm{C}$ and stirred $(800 \mathrm{rpm})$ for $2 \mathrm{~min}$ to dissolve the complex in the molten naphthalene, and allowed to stand for $15 \mathrm{~min}$ at room temperature to form microcrystalline naphthalene containing AFD complex. After filtration with fritted glass, this microcrystalline naphthalene was washed with deionized water and dissolved in a $2 \mathrm{~mL}$ volumetric flask with acetone. The absorbance of the solutions was measured at $228.8 \mathrm{~nm}$ with graphite furnace atomic absorption spectrometer. A calibration curve was prepared in the range $0-40 \mathrm{ngm} / \mathrm{L}$. The amounts of the dyes adsorbed onto compost (qe in $\mathrm{mg} / \mathrm{m}$ ) were calculated from the equation:

$$
q_{e}=\frac{\left(C_{o}-C_{e}\right) * V}{m}
$$

...where $C_{o}$ and $C_{e}$ are the initial and equilibrium concentrations of copper in solution $(\mathrm{mg} / \mathrm{L}) ; V$ is the volume of solution (L), and $m$ is the mass of adsorbent $(\mathrm{g})$.

\section{Results and Discussion}

\section{Characterization}

The peaks at 3,406, 3,641, 1,616, and $833 \mathrm{~cm}^{-1}$ constitute the characteristic peaks of zeolite (Fig. 2). Two peaks appearing between 3406 and $3641 \mathrm{~cm}^{-1}$ belong to bond vibrations between the hydroxyl groups in zeolite structure and between aluminum with tetrahedral structure and nonacidic end silinol group (Fig. 2A). The bands around 3660 $\mathrm{cm}^{-1}$ belong to extra-lattice aluminum. After adsorption of AFD onto zeolite surface, the bands were observed at
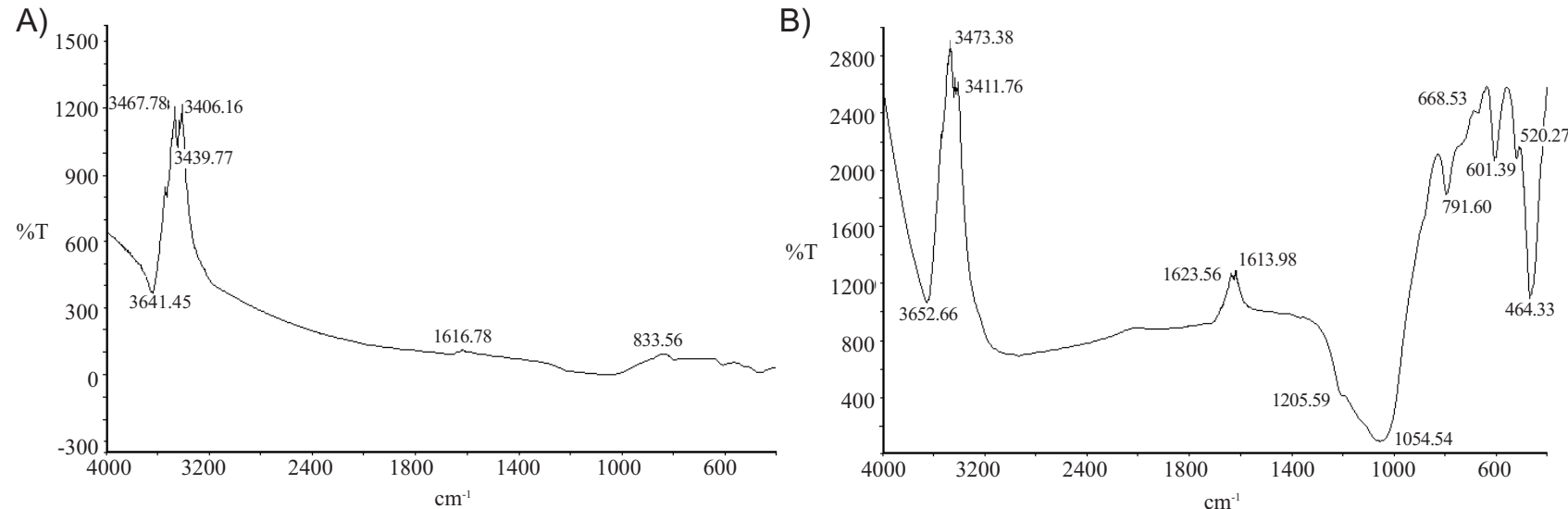

Fig. 2. FT-IR spectrum of adsorbent (A) and adsorbent loaded with AFD (B).
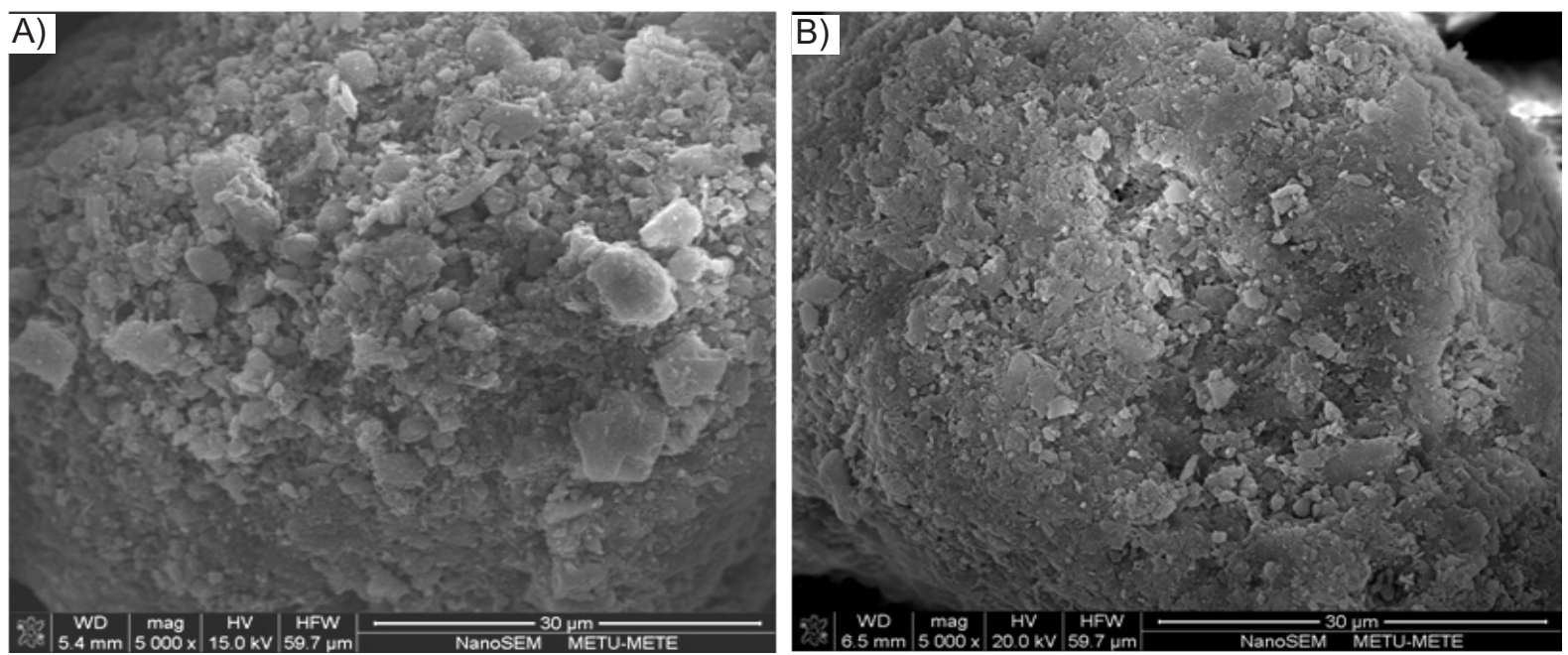

Fig. 3. SEM images of native zeolite (A) and AFD-loaded laccase-modified zeolite (B). 
$1,054-1,205 \mathrm{~cm}^{-1}$. These bands show the hydrogen connected to nitrogen atoms in AFD structure and the vibrations belonging to binding on the zeolite surface. The mechanistic interaction between AFD and zeolite on the bonds located between 464 and $668 \mathrm{~cm}^{-1}$ can be explained by AFD$\mathrm{O}(\mathrm{H}) \mathrm{Si}$ vibrations (Fig. 2B). There is no significant change in the functional biomass groups of zeolite after adsorption of AFD on the zeolite when AFD were treated with zeolite. It was concluded that AFD did no damage to functional groups on the adsorbent [23].

The SEM is useful for determining the particle shape, porosity and appropriate size distribution of the adsorbent $[24,25]$. The SEM images of LMZ and AFD-adsorbed LMZ are shown in Fig. 3 (A-B). It is clear that zeolite has a considerable number of pores where there is a good possibility for dyes to be trapped and adsorbed. Based on analysis of the images taken by SEM before and after the dye adsorption process, highly heterogeneous pores within zeolite particles were observed. After the adsorption process, the pores were packed with AFD and this finding revealed the coverage of the modified material surface with a molecular cloud of dye [26].

The EDX measurements were illustrated in Fig. 4 (AB). From the EDX spectra, the AFD ions were adsorbed onto the LMZ adsorbent. It is shown from EDX spectra that after AFD adsorption, element concentrations increased in the AFD-loaded adsorbent (Table 1). The adsorption of AFD onto LMZ was also evidenced by an increase of the K, $\mathrm{Ca}, \mathrm{Ti}, \mathrm{Fe}$, and $\mathrm{Cu}$ signals in the EDX spectrum of dyeloaded LMZ since these elements were present in the dye structure. It was also noted that the intensities of the $\mathrm{Na}, \mathrm{Si}$ and $\mathrm{Al}$ peaks in the EDX spectrum of zeolite decreased after
A

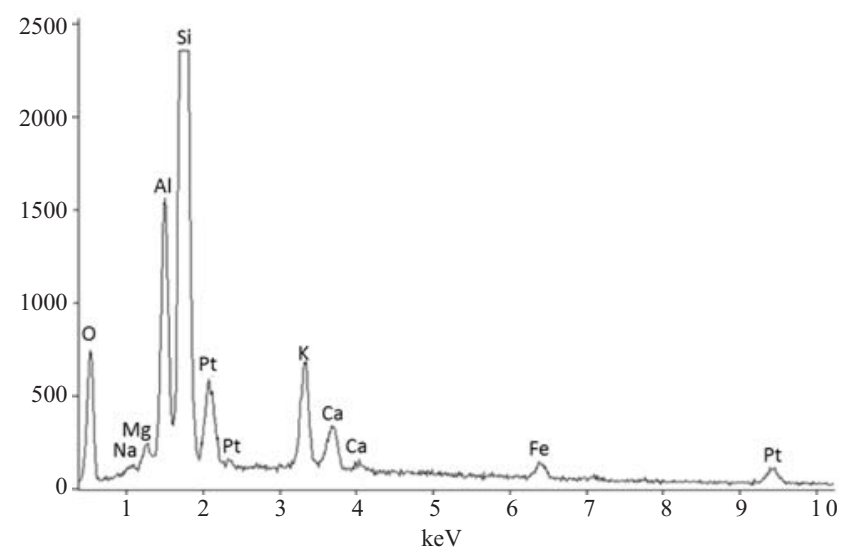

B

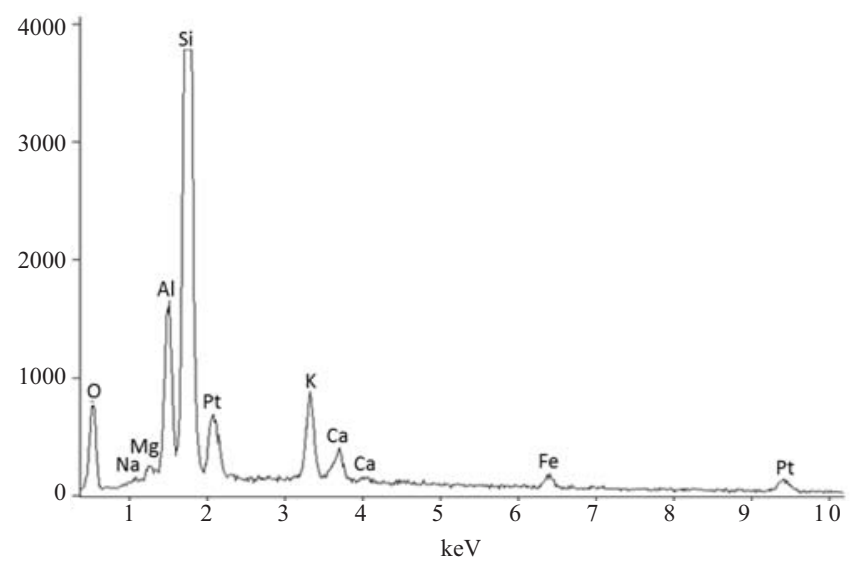

Fig. 4. EDX spectra of zeolite (A) and AFD-loaded laccase-modified zeolite (B).
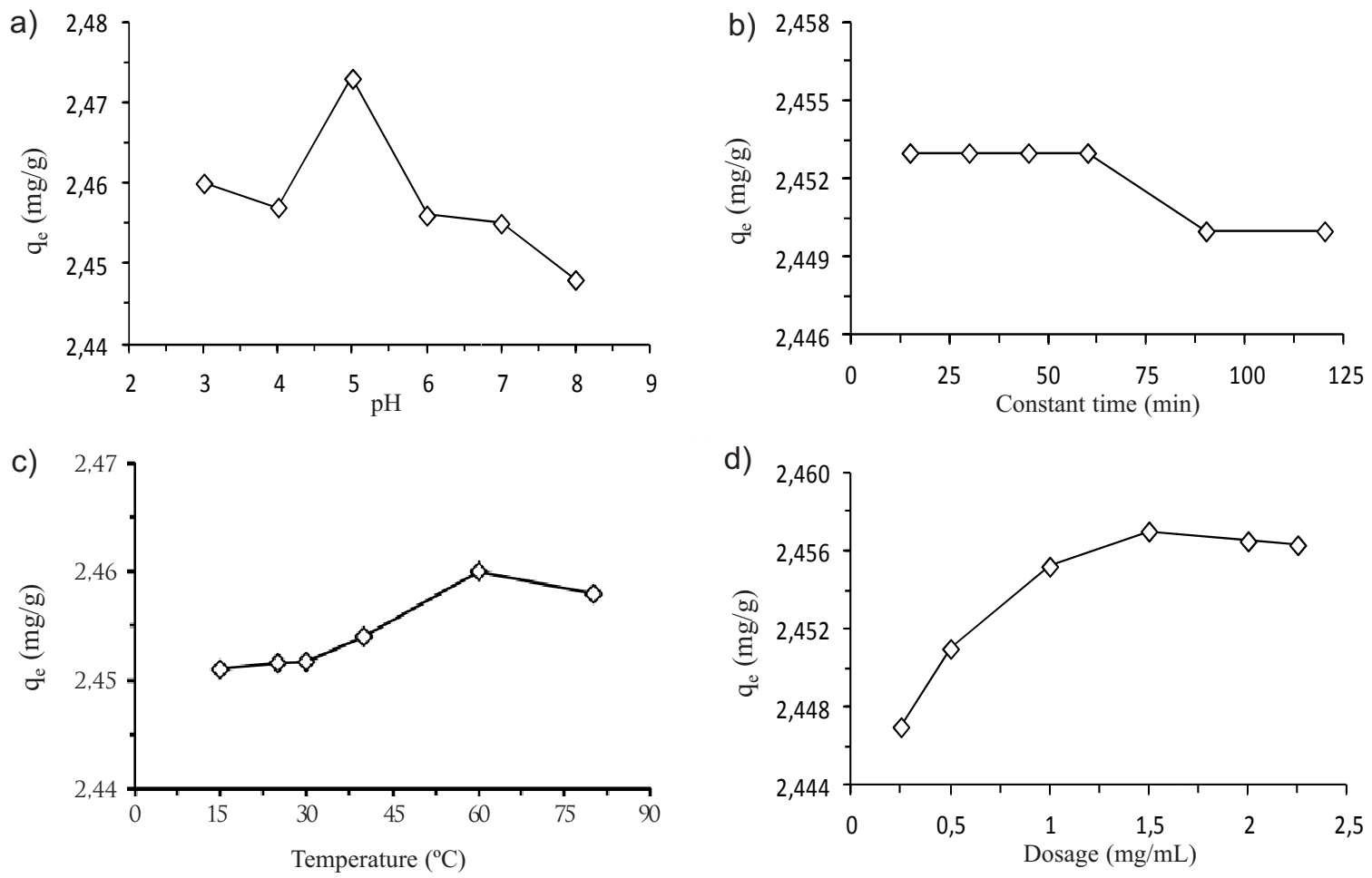

Fig. 5. Effect of $\mathrm{pH}(\mathrm{a})$, contact time (b), temperature (c), and dosage (d) on removal of AFD by laccase-modified zeolite. 
Table 1. Results of EDX spectrum.

\begin{tabular}{|c|c|c|c|c|}
\hline \multirow{2}{*}{ Elements } & \multicolumn{2}{|c|}{$\begin{array}{c}\text { Native adsorbent } \\
\text { (zeolite) }\end{array}$} & \multicolumn{2}{c|}{$\begin{array}{c}\text { AFD-loaded adsorbent } \\
\text { (laccase-modified } \\
\text { zeolite) }\end{array}$} \\
\cline { 2 - 5 } & Weight (\%) & Atom (\%) & Weight (\%) & Atom (\%) \\
\hline $\mathrm{Na}$ & 0.68 & 0.87 & 0.48 & 0.62 \\
\hline $\mathrm{Mg}$ & 1.00 & 1.21 & 0.85 & 1.04 \\
\hline $\mathrm{Al}$ & 11.90 & 12.97 & 11.18 & 12.25 \\
\hline $\mathrm{Si}$ & 69.86 & 73.18 & 70.18 & 73.89 \\
\hline $\mathrm{K}$ & 9.27 & 6.97 & 9.80 & 7.41 \\
\hline $\mathrm{Ca}$ & 4.58 & 3.36 & 3.91 & 2.89 \\
\hline $\mathrm{Fe}$ & 2.72 & 1.43 & 3.59 & 1.90 \\
\hline
\end{tabular}

AFD adsorption [6]. This may be regarded as an ion exchange mechanism in addition to other possible interactions.

\section{Adsorption Studies}

The experiments were carried out at different initial $\mathrm{pH}$ values ranging from 3 to 8 and the optimum $\mathrm{pH}$ was obtained as 5 (Fig. 5a). Several reasons may be attributed to dye adsorption behavior of the adsorbent relative to solution $\mathrm{pH}$. The surface of LMZ may contain a large number of active sites and the removal of dye ions can be related to the active sites and also to the chemistry of the dye ions in the solution [27]. At lower $\mathrm{pH}$ more protons will be available, thereby increasing electrostatic attractions between negatively charged dye anions and positively charged adsorption sites and causing an increase in dye adsorption. When the $\mathrm{pH}$ of the solution is increased, the positive charge on the oxide or solution interface decreases and the adsorbent surface becomes negatively charged. Therefore, the lower adsorption at higher $\mathrm{pH}$ may be due to the abundance of $\mathrm{OH}^{-}$ions and, consequently, ionic repulsion between the negatively charged surface and the anionic dye molecules. Also, there are no exchangeable anions on the outer surface of the adsorbent at higher $\mathrm{pH}$ values, and consequently adsorption decreases [28].

The effect of contact time on the removal of AFD was investigated at time interval 0-120 min and the results were shown in Fig. 5b. The removal increased quickly within the initial $60 \mathrm{~min}$ and remained almost unchanged after $90 \mathrm{~min}$, indicating the reaching of an apparent equilibrium. Rapid absorption and equilibrium in a short period of time is related to the efficacy of the adsorbent, especially for wastewater treatment $[29,30]$. At the initial stage, the rate of removal of AFD was higher due to the availability of more than the required number of active sites on the surface of the adsorbent. The rate of the removal became slower at the later stages of contact time, due to the decreased or lesser number of active sites [31]. As the surface adsorption sites become exhausted, the uptake rate is controlled by the rate at which the adsorbate is transported from the exterior to
Table 2. Values of the Langmuir and Freundlich adsorption isotherms.

\begin{tabular}{|c|c|c|c|}
\hline \multicolumn{2}{|c|}{ Langmuir constants } & \multicolumn{2}{c|}{ Freundlich constants } \\
\hline$q_{\max }(\mathrm{mg} / \mathrm{g})$ & 200.00 & $K_{F}$ & 6.140 \\
\hline$b(\mathrm{~L} / \mathrm{mg})$ & 31.00 & $n$ & 0.399 \\
\hline $\mathrm{R}^{2}$ & 0.987 & $\mathrm{R}^{2}$ & 0.976 \\
\hline
\end{tabular}

the interior sites of the adsorbent particles [32]. The rapid removal has significant practical importance because it will facilitate a smaller reactor volume, ensuring efficiency and economy $[33,34]$.

The degree of adsorption increases with increasing temperature, and maximum adsorption is obtained at $60^{\circ} \mathrm{C}$, which is the temperature of the solution for the LMZ (Fig. $5 \mathrm{c})$. The temperature increase favors dye adsorption, with $60^{\circ} \mathrm{C}$ showing greater color removal efficiency compared to the other temperatures. This increase also affects the solubility and chemical potential of the adsorbate, possibly becoming a factor that controls adsorption [35]. An increase in temperature involves increased mobility of the metal ions and a decrease in the retarding forces acting on the diffusing ions. These result in enhancing the adsorptive capacity of the adsorbent [36]. The temperature dependence of the adsorption process is associated with changes in several thermodynamic parameters [37].

The effect of the adsorbent dosage was studied by varying the adsorbent amounts from 0.25 to $2.0 \mathrm{mg} / \mathrm{mL}$. The effect of LMZ dosage on amount of AFD adsorbed was shown in Fig. 5d. A trend of increase in adsorption capacity with increase in adsorbent dosage was observed from 0.25 to $1.50 \mathrm{mg} / \mathrm{mL}$. Any further addition of the adsorbent beyond this did not cause any significant changes in adsorption. The amount of maximum AFD removal was 2.457 $\mathrm{mg} / \mathrm{g}$ at $1,500 \mathrm{mg} / \mathrm{mL}$ of adsorbent dose. Iincreasing dye removal with adsorbent dosage can be attributed to an increase of adsorbent surface and availability of more adsorption sites. However, the capacity decreased with the increasing amount of adsorbent when the adsorption capacity was expressed in $\mathrm{mg}$ adsorbed per gram of material. This can be attributed to overlapping or aggregation of adsorption sites, resulting in a decrease in total adsorbent surface area available to the dye and an increase in diffusion path length $[38,39]$.

\section{Adsorption Isotherms}

In this study the suitability of the Langmuir and Freundlich adsorption isotherm models to the equilibrium data were investigated for removal of AFD using LMZ. The Langmuir adsorption isotherm model assumes that adsorption occurs on a homogenous adsorbent surface of identical sites that are equally available and energetically equivalent with each site and carry equal numbers of molecules with no interaction between adsorbate molecules [40, 41]. The Langmuir adsorption isotherm was determined from a linear form of Eq. 2: 
Table 3. Comparison between the estimated adsorption rate constants, $q_{e}$, and correlation coefficients associated with the pseudo-firstorder and the pseudo-second-order rate equations.

\begin{tabular}{|c|c|c|c|c|c|c|c|}
\hline & & \multicolumn{3}{|c|}{ Pseudo-first-order rate equation } & \multicolumn{3}{|c|}{ Pseudo-second-order rate equation } \\
\hline $\begin{array}{c}\text { Initial AFD } \\
\text { concentration }(\mathrm{mg} / \mathrm{L})\end{array}$ & $\begin{array}{c}q_{e} \text { expected } \\
(\mathrm{mg} / \mathrm{g})\end{array}$ & $k_{1}$ & $\begin{array}{c}q_{e} \text { calculated } \\
(\mathrm{mg} / \mathrm{g})\end{array}$ & $\mathrm{R}^{2}$ & $\mathrm{k}_{2}$ & $\begin{array}{c}q_{e} \text { calculated } \\
(\mathrm{mg} / \mathrm{g})\end{array}$ & $\mathrm{R}^{2}$ \\
\hline 5 & 2.48 & 0.028 & 1.32 & 0.972 & 0.56 & 2.53 & 0.918 \\
\hline 25 & 18.76 & 0.032 & 17.2 & 0.982 & 0.002 & 23.75 & 0.973 \\
\hline 50 & 27.63 & 0.030 & 20.39 & 0.984 & 0.000574 & 30.49 & 0.983 \\
\hline
\end{tabular}

$$
\frac{C_{e}}{q_{e}}=\frac{1}{b^{*} q_{\max }}+\frac{C_{e}}{q_{\max }}
$$

...where $q_{\max }(\mathrm{mg} / \mathrm{g})$ and $b(\mathrm{~L} / \mathrm{mg})$ are Langmuir constants, which are indicators of the maximum adsorption capacity and the affinity of the binding sites, respectively.

The values of $q_{\max }$ and $b$ were calculated from the slope and intercept of the Langmuir plot of $C_{e}$ versus $C_{e} / q_{e}$ from Fig. 6a, the empirical constants $q_{\max }$ and $b$ were found to be $200 \mathrm{mg} / \mathrm{g}$ and $31 \mathrm{~L} / \mathrm{mg}$ (Table 2), respectively. The correlation coefficient reported in Table 2 showed strong positive evidence on the adsorption of AFD, and LMZ follows the Langmuir isotherm. The applicability of the linear form of Langmuir model to LMZ was proved by the high correlation coefficient $R^{2}(0.987)>0.95$. This suggests that the Langmuir isotherm provides a good model of the sorption system.

The Freundlich isotherm assumes that the adsorption occurs on heterogeneous surfaces at sites with different energy of adsorption and with non-identical adsorption sites that are not always available [41, 42]. The Freundlich constants can be calculated in the following linear form:

$$
\log q_{e}=\log K_{F}+\frac{1}{n} \log C_{e}
$$

...where $K_{F}$ and $\mathrm{n}$ are the Freundlich constants related to the sorption capacity of the adsorbent $(\mathrm{mg} / \mathrm{g})$ and the energy of adsorption, respectively.

$K_{F}$ and $n$ values were calculated from the intercept and slope of the plot (Fig. 6b). In the literature, it is pointed out that the parameters, $K_{F}$ and $\mathrm{n}$ affect the adsorption isotherm.

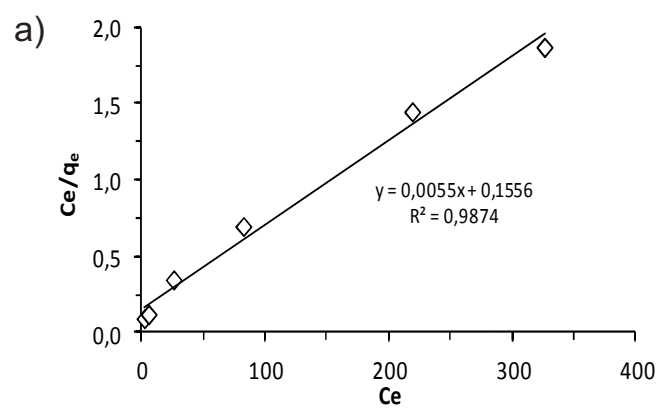

Fig. 6. Langmuir (a) and Freundlich (b) adsorption isotherms.
The larger $K_{F}$ and n values indicate the higher the adsorption capacity. The magnitude of exponent $\mathrm{n}$ gives an indication of the favorability of the adsorption. The $n$ value is 0.399 (Table 2) and is a good adsorption characteristic [43]. Based on the high correlation coefficient $\mathrm{R}^{2}(0.976)>0.95$, it has been deduced that the Freundlich model is better fitted to the experimental data.

\section{Adsorption Kinetics}

The pseudo-first-order kinetic model is widely employed to understand the kinetic behavior of the adsorption reactions [44].

$$
\frac{1}{q_{t}}=\frac{k_{1}}{q_{e} t}+\frac{1}{q_{e}}
$$

...where $q_{e}$ and qt are the amounts of AFD adsorbed at equilibrium and at time $t\left(\mathrm{mg} \cdot \mathrm{g}^{-1}\right)$, and $k_{1}$ is the pseudo-firstorder rate constant $\left(\mathrm{min}^{-1}\right)$. The $k_{1}$ and the correlation coefficients for AFD adsorption at different concentrations ranging from 5 to $50 \mathrm{mg} / \mathrm{L}$ were calculated from the linear plots of $\ln \left(q_{e}-q_{t}\right)$ versus $t$ (Fig. 7) and were listed in Table 3. The correlation coefficients for the pseudo-first-order kinetic model were high ranging from 0.972 and 0.984 . Moreover, a large difference of equilibrium adsorption capacity $\left(q_{e}\right)$ between the experiment and calculation was observed, indicating a high pseudo first-order fit to the experimental data. These results confirm the better adsorption capacity of the LMZ.

The adsorption kinetics can also be described by a pseudo-second-order reaction. The pseudo-second-order kinetic model is based on the assumption that the limiting rate step

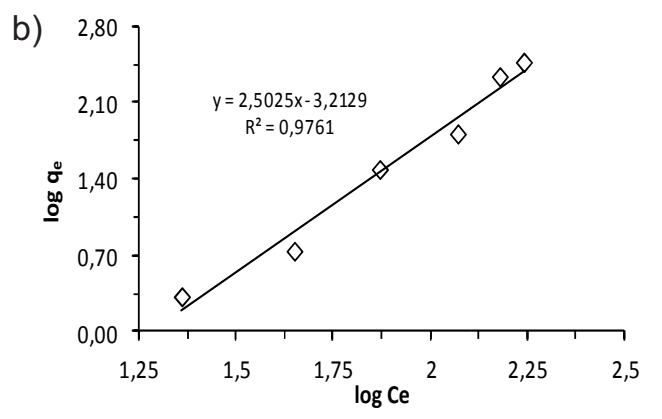


may be chemisorption, which involves valence forces by sharing or electron exchange between the adsorbent and the adsorbate $[45,46]$. The pseudo-second-order kinetic model is given by the following equation.

$$
\frac{1}{q_{t}}=\frac{k_{2}}{q_{e}^{2}}+\frac{t}{q_{e}}
$$

...where $k_{2}$ is the equilibrium rate constant of pseudo-second-order model $\left(\mathrm{g} \cdot \mathrm{mol}^{-1} \cdot \mathrm{min}^{-1}\right)$. The $k_{1}, q_{e}$, and the correlation coefficients for AFD adsorption at different concentrations ranging from 5 to $50 \mathrm{mg} / \mathrm{L}$ were calculated from the linear plots of $t / q_{t}$ versus $t$ (Fig. 8) and were listed in Table 3. At all initial acid fuchsin dye concentrations studied, straight lines with high correlation coefficients were obtained. The correlation coefficients for the pseudo-second-order kinetic model were high, ranging from 0.973 and 0.983 . The $k_{2}$ decreases with an increase in initial AFD concentration. The reason for this behavior can be attributed to the lower competition for the adsorption surface sites at lower concentrations. At higher concentrations, the competition for the surface active sites is high and, consequently, lower sorption rates are obtained. The equilibrium adsorption capacity $\left(q_{e}\right)$, however, increased with an increase in initial AFD concentration because a large number of AFD ions are adsorbed at the available adsorption sites [47-49].
Table 4. Thermodynamic parameters for the AFD dye adsorption.

\begin{tabular}{|c|c|c|c|}
\hline \multirow{2}{*}{$\begin{array}{c}\text { Temperature } \\
(\mathrm{K})\end{array}$} & \multicolumn{3}{|c|}{ Thermodynamic parameters } \\
\cline { 2 - 2 } & $\Delta G^{\mathrm{o}}\left(\mathrm{kJmol}^{-1}\right)$ & $\Delta H^{\mathrm{o}}\left(\mathrm{kJmol}^{-1}\right)$ & $\Delta S^{\mathrm{o}}\left(\mathrm{Jmol}^{-1}\right)$ \\
\hline 298 & -18.6169 & & \\
\hline 303 & -18.9348 & \multirow{2}{*}{9.087} & 63.57 \\
\hline 313 & -19.2526 & & \\
\hline
\end{tabular}

\section{Thermodynamic Studies}

Thermodynamic parameters, including change in Gibbs free energy $\left(\Delta G^{\circ}\right) \mathrm{kJ} / \mathrm{mol}$, enthalpy $\left(\Delta H^{\circ}\right) \mathrm{kJ} / \mathrm{mol}$, and entropy $\left(\Delta S^{\mathrm{o}}\right) \mathrm{J} / \mathrm{Kmol}$, are the actual indicators for practical application of an adsorption process. According to the values of these parameters, what process will occur spontaneously can be determined [25]. The Gibbs free energy change is an indication of spontaneity of a chemical reaction and therefore is an important criterion for spontaneity. Both energy and entropy factors must be considered in order to determine the Gibbs free energy of the process $[50,51]$. The aim of thermodynamic study is to establish the thermodynamic parameters that can characterize the adsorption process. The adsorption capacity of LMZ adsorbent increased with increases in the tempera-
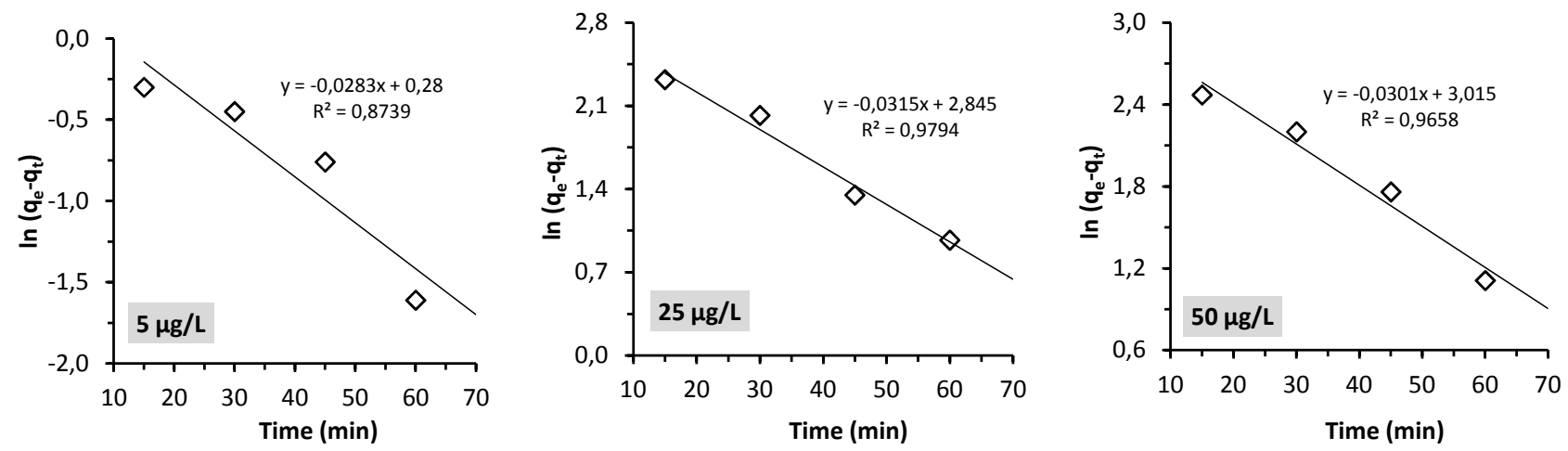

Fig. 7. Pseudo-fist-order reaction for AFD adsorbed onto laccase-modified zeolite at different concentrations.
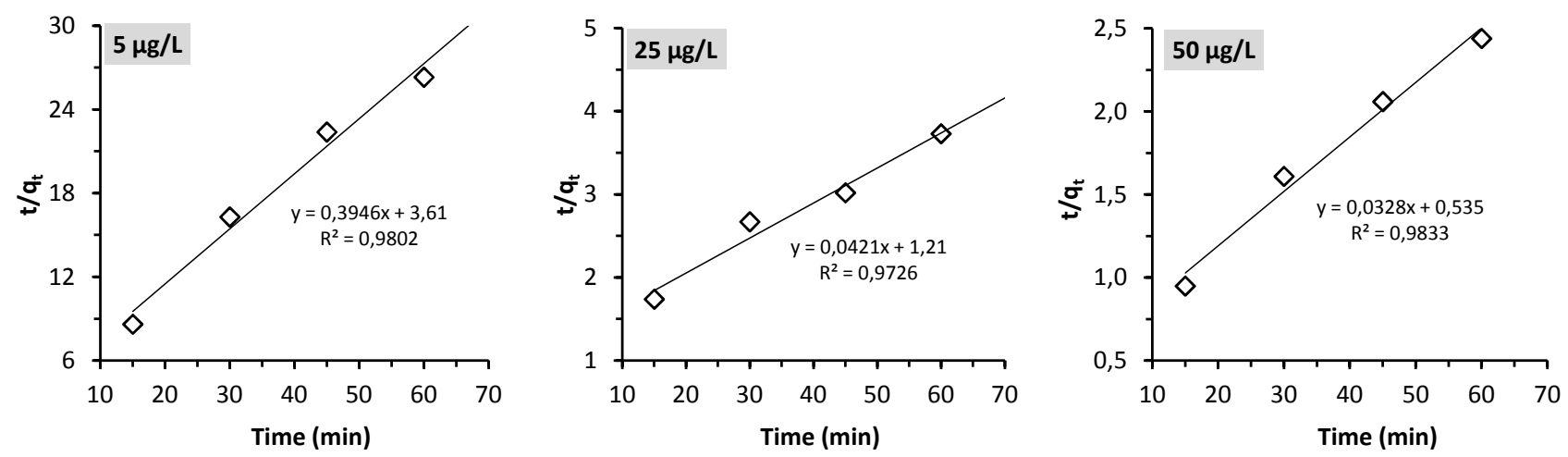

Fig. 8. Pseudo-second-order reaction for AFD adsorbed onto laccase-modified zeolite at different concentrations. 


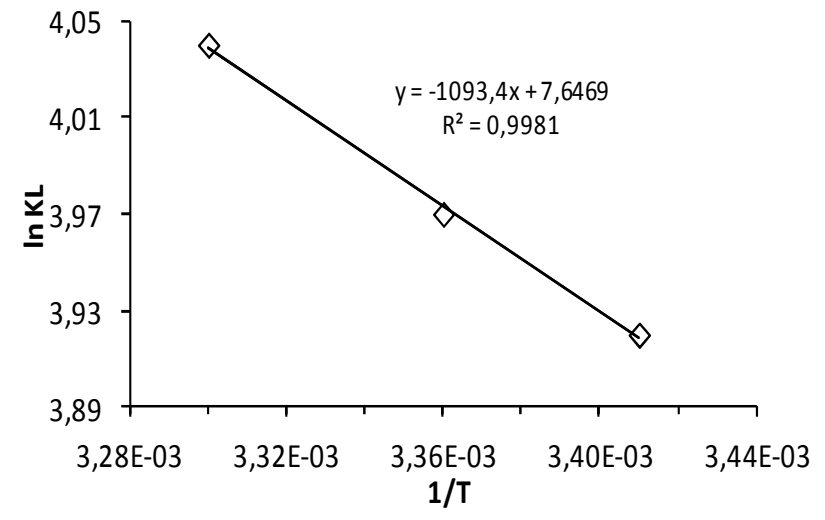

Fig. 9. Influence of temperature on the thermodynamic behavior of AFD.

ture of the system from 293-303 K. The thermodynamic parameters were determined using the following equations $[52,53]$ :

$$
\begin{gathered}
K_{L}=\frac{C_{s}}{C_{e}} \\
\Delta G^{o}=-R T \ln K_{L} \\
\ln K_{L}=\left(\frac{\Delta S^{o}}{R}\right)-\left(\frac{\Delta H^{o}}{R T}\right)
\end{gathered}
$$

...where $K_{L}$ is the equilibrium constant, $C_{s}$ is the solid phase concentration at equilibrium $(\mathrm{mg} / \mathrm{L}), C_{e}$ is the liquid phase concentration at equilibrium $(\mathrm{mg} / \mathrm{L}), \mathrm{T}$ is the temperature in Kelvin, and $R$ is the gas constant. $\Delta H^{\circ}$ and $\Delta S^{\circ}$ values are obtained from the slope and intercept of plot $\ln K_{o}$ against $1 / \mathrm{T}$ [54]. Von't Hoff plot of effect of temperature on adsorption of AFD on LMZ was illustrate on Fig. 9 and values were summarized in Table 4.

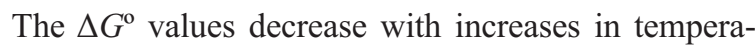
ture, indicating an increased trend in the degree of spontaneity and feasibility of AFD adsorption. In the case of AFD adsorption onto LMZ, the values of Gibbs free energy of the process at all temperatures are negative. The $\Delta G^{\circ}$ values are found to decrease as the temperature increases in both dye-anion exchanger systems, suggesting that higher temperatures make the adsorption easier. The negative value of $\Delta G^{\mathrm{o}}$ indicates the adsorption is favorable and spontaneous [55]. The negative values of $\Delta H^{\circ}$ further confirm the exothermic nature of the adsorption process. Hence, the adsorption of AFD on LMZ is chemical in nature. The positive values of $\Delta S^{\mathrm{o}}$ indicate good affinity of the anion exchangers for AFD molecules and show an increase in the degree of freedom for the adsorbed species $[55,56-58]$.

\section{Conclusion}

In this study, the LMZ for removal of AFD from aqueous solution was investigated. Batch adsorption experiments were carried out as a function of $\mathrm{pH}$, contact time, temperature, and adsorbent dosage. The experiments indicated that LMZ was effective in removal of AFD from aqueous solutions. For equilibrium studies, two isotherm models were used in this study (Freundlich and Langmuir models) for different temperatures, and it is found that the Langmuir model fitted experimental data very well. The kinetics of AFD adsorption on LMZ is best described with the pseudo-first-order kinetics model with correlation coefficient of 0.984 . Thermodynamic parameters including Gibbs free energy, enthalpy, and entropy changes indicated that the adsorption of AFD onto LMZ adsorbent was feasible, spontaneous, and endothermic. Results showed that the LMZ could be an alternative adsorbent material for AFD removal from aqueous solution.

\section{Acknowledgements}

This research has been performed under project No. 2013/68 and supported by the Research Development Center of Ataturk University.

\section{References}

1. ATAR N., OLGUN A. Removal of basic and acid dyes from aqueous solutions by a waste containing boron impurity. Desalination, 249, 109, 2009.

2. AKAR ST., BALK YY., TUNA O., AKAR T. Improved biosorption potential of Thuja orientalis cone powder for the biosorptive removal of Basic Blue 9. Carbohyd. Polym, 94, (1), 400, 2013.

3. OZER A., AKKAYA G., TURABIK M. The removal of Acid Red 274 from wastewater: Combined biosorption and biocoagulation with Spirogyra rhizopus. Dyes Pigments, 71, 83, 2006.

4. SHI B., LI G., WANG D., FENG C., TANG H. Removal of direct dyes by coagulation: The performance of preformed polymeric aluminum species. J. Hazard. Mater., 143, 567, 2007.

5. ZONOOZI MH., MOGHADDAM MRA., ARAMI M. Removal of acid red 398 dye from aqueous solutions by coagulation/flocclation process. Environ. Eng. Manage. J., 7, (6), 695, 2008.

6. KALKAN E., NADAROGLU H., CELEBI N., TOZSIN G., Removal of textile dye Reactive Black 5 from aqueous solution by adsorption on laccase-modified silica fume. Desalination Water Treat., doi: 10.1080/19443994.2013.811114, 2013.

7. NADAOGLU H., CELEBI N., KALKAN E., DIKBAS N. The evaluation of affection of Methylobacterium extorquens-modified silica fume for adsorption cadmium (II) ions from aqueous solutions affection. J. Fac. Veter. Medic. Kafkas Univ., 19, (3), 391, 2013.

8. ROBINSON T., CHANDRAN B., NIGAM P. Removal of dyes from a synthetic textile dye effluent by biosorption on apple pomace and wheat straw. Water Res., 36, 2824, 2002.

9. RAVIKUMAR K., RAMMALINGAM S., KRISHAN S., BALU K. Application of response surface methodology to optimize the process variables for reactive red and acid Brown dye removal using a novel adsorbent. Dyes Pigments, 70, 18, 2006.

10. GUPTA VK., JAIN R., MITTAL A., MATHUR M., SIKARWAR S. Photochemical degradation of the hazardous dye Safranin-T using $\mathrm{TiO}_{2}$ catalyst. J. Colloid Interf. Sci., 309, 464, 2007. 
11. JAIN R., MATHUR M., SIKARWAR S., MITTAL A. Removal of the hazardous dye rhodamine B through photocatalytic and adsorption treatments. J. Environ. Manage., 85, 956, 2007.

12. ELIZALDE-GONZALEZ MP., FUENTES-RAMIREZ LE., GUEVARE-VILLA MRG. Degradation of immobilized azo dyes by Klebsiella sp. UAP-b5 isolated from maize bioadsorbent. J. Hazard. Mater., 161, 769, 2009.

13. KYZAS GZ. Commercial coffee wastes as materials for adsorption of heavy metals from aqueous solutions. Mater., 5, 1826, 2012

14. KYZAS GZ., LAZARIDIS NK., MITROPOULOS ACH. Removal of dyes from aqueous solutions with untreated coffee residues as potential low-cost adsorbents: Equilibrium, reuse and thermodynamic approach. Chem. Eng. J., 189190, 148, 2012.

15. WENG CH., PAN YF. Adsorption of a cationic dye (methylene blue) onto spent activated clay. J. Hazard. Mater., 144, 355, 2007.

16. YOUSEF RI., El-ESWED B., AL-MUHTASEB AH. Adsorption characteristics of natural zeolites as solid adsorbents for phenol removal from aqueous solutions: kinetics, mechanism, and thermodynamics studies. Chem. Eng. J., 171, 1143, 2011.

17. AHMARUZZAMAN M. Adsorption of phenolic compounds on low-cost adsorbents: a review. Adv. Colloid Interf. Sci., 143, 48, 2008.

18. IMRAN M., ASAD M., HADRI SH., MEHMOOD S. Production and industrial applications of laccase enzyme. J. Cell Mol. Biol., 10, (1), 1, 2012.

19. NEILSEN LF., MOE D., KIRKEBY S., GARBARSCH C. Sirius red and acid fuchsin staining mechanisms. Biotechnic Histochem., 73, 71, 1998.

20. ZOBIR BIN HUSSEIN M., YAHAYAAH., SHAMSUL M., SALLEH HM., YAP T., KIU J. Acid fuchsin-interleaved Mg-Al-layered double hydroxide for the formation of an organic-inorganic hybrid nanocomposite. Mater. Letter, 58, 329, 2004.

21. AYDIN F., KULEYIN A. The Effect of Modification and Initial Concentration on Ammonia Removal from Leachate by Zeolite. World Acad. Sci. Eng. Technol., 54, 293, 2011.

22. ZHANG GQ., WANGA YF., ZHANG XQ., NG TB., WANGA HX. Purification and characterization of a novel laccase from the edible mushroom Clitocybe maxima. Proc. Biochem., 45, 627, 2010.

23. JACOBS PA., von BALLMOOS R. Framework of hydroxyl groups of H-ZSM-5 zeolites. J. Phy. Chem., 86, 3050, 1982.

24. ARAMI M., LIMAEE NY., MAHMOODI NM. Evaluation and adsorption kinetics and equilibrium for the potential removal of acid dyes using a biosorbent. Chem. Eng. J., 139, $2,2008$.

25. MAHMOODI NM., HAYATI B., ARAMI M. Kinetic, equilibrium and thermodynamic studies of ternary system dye removal using a biopolymer. Ind. Crop Product, 35, 295, 2012

26. MAHMOODI NM., SALEHI R., ARAMI M., BAHRAMI $\mathrm{H}$. Dye removal from coloured textile wastewater using chitosan in binary systems. Desalination, 267, 64, 2011.

27. SRIVASATA R., RUPAINWAR DC. Removal of hazardous triphenylmethane dye through adsorption over waste material-mango bark powder. Indian J. Chem. Technol., 18, 469, 2011.

28. OZCAN AS., OZCAN A. Adsorption of acid dyes from aqueous solutions onto acid activated bentonite. J. Colloid Interf. Sci., 276, 39, 2004.
29. DOTTO GL., PINTO LAA. Adsorption of food dyes acid blue 9 and food yellow 3 onto chitosan: Stirring rate effect in kinetics and mechanism. J. Hazard. Mater., 187, 164, 2011.

30. PEREIRA de SA F., CUNHA BN., NUNES LM. Effect of $\mathrm{pH}$ on the adsorption of Sunset Yellow FCF food dye into a layered double hydroxide (CaAl-LDH- $\left.\mathrm{NO}_{3}\right)$. Chem. Eng. J., 215, 122, 2013.

31. HILAL NM., AHMED IA., BADR EE. Removal of acid dye (AR37) by adsorption onto potatoes and egg husk: a comparative study. J. American Sci., 8, (2), 341, 2012.

32. NADAROGLU H., KALKAN E., CELEBI N. Equilibrium, kinetic and thermodynamic studies on adsorption of Reactive Black 5 dye by laccase modified-red mud from aqueous solutions. Fresenius Environ. B., 23, (1), 70, 2013.

33. MOHAN D., PITTMAN CU. Arsenic removal from water/wastewater using adsorbents - a critical review. J. Hazard. Mater., 142, 1, 2007.

34. DHABAB JM. Removal of some heavy metal ions from their aqueous solutions by duckweed. J. Toxic. Environ. Health Sci., 3, (6), 164, 2011.

35. CHIARELLO LM., BARCELLOS IO., SPENGLER G., ROZA DE. Treatment of acidic dyes solutions by adsorption in soybean meal. Acta Scientiarum, 34, 97, 2012

36. ELOUEAR Z., BOUZID J., BOUJELBEN N., FEKI M., JAMOUSSI F., MONTIEL A. Heavy metal removal from aqueous solutions by activated phosphate rock. J. Hazard. Mater., 156, 412, 2008.

37. DAS J., PATRA BS., BALIARSINGH N., PARIDA KM. Adsorption of phosphate by layered double hydroxides in aqueous solutions. Applied Clay Science, 32, 252, 2006.

38. CRINI G., GIMBERT F., ROBERT C., MARTEL B., ADAM O., MORIN-CRINI N., DE GIORGI F., BADOT P$M$. The removal of Basic Blue 3 from aqueous solutions by chitosan-based adsorbent: Batch studies. J. Hazard. Mater., 153, (1-2), 96, 2008.

39. MAHMOODI MM. Synthesis of core-shell magnetic adsorbent nanoparticle and selectivity analysis for binary system dye removal. J. Ind. Eng. Chem., 2013 [In Press].

40. AL-DURI B., YONG YP. Lipase immobilisation: an equilibrium study of lipases immobilised on hydrophopic and hydrophilic/hydrophopic supports. Biochem. Eng. J., 4, 207, 2000.

41. EL QADA EN., ALLEN SJ., WALKER GM. Adsorption of Methylene Blue onto activated carbon produced from steam activated bituminous coal: A study of equilibrium adsorption isotherm. Chem. Eng. J., 124, 103, 2006.

42. WALKER G., WEATHERLEY L. Adsorption of dyes from aqueous solution-the effect of adsorbent pore size distribution and dye aggregation. Chem. Eng. J., 83, 201, 2001.

43. TREYBAL RE. Mass transfer operations, $3^{\text {nd }}$ edition New York McGraw Hill, 447, 1980.

44. HO YS. Citation review of Langergren kinetic rate equation on adsorption reaction. Scientometrics 59, 171, 2004.

45. WANG L., WANG A. Adsorption properties of Congo red from aqueous solution onto surfactant-modified montmorillonite. J. Hazard. Mater., 160, 173, 2008.

46. KANNAN N., VEEMARAJ K. Removal of lead (II) ions by adsorption onto bamboo dust and commercial activated carbons-A comparative study. E-J. Chem., 6, (2), 247, 2009.

47. LAROUS S., MENIAI A-H., LEHOCINE MB. Experimental study of the removal of copper from aqueous solutions by adsorption using sawdust. Desalination, $\mathbf{1 8 5}$, 483, 2005. 
48. KUMAR PS., RAMAKRISHNAN K., KIRUPHA SD. SIVANESAN S. Thermodynamic and kinetic studies of cadmium adsorption from aqueous solution onto rice husk. Braz. J. Chem. Eng., 27, (2), 347, 2010.

49. NADAROGLU H., CELEBI N., KALKAN E., TOZSIN G. Water purification of textile dye Acid red 37 by adsorption on laccase-modified silica fume. Jokull J., 63, (5), 87, 2013.

50. AWALA HA., EL JAMAL MN. Equilibrium and kinetics study of adsorption of some dyes onto feldspar. J. Univ. Chem. Technol. Metallurgy, 46, (1), 45, 2011.

51. JANVEJA B., SHARMA J., KANT K. Thermodynamic study of adsorption of amaranth dye on to steam activated pigmented rice husk carbon. J. Int. Acad. Phy. Sci., 15, (3), 395, 2011

52. NAMASIVAYAM C., KAVITHA D. Removal of Congo red from water by adsorption onto activated carbon prepared from coir pith, agricultural solid waste. Dye Pigment, 54, 47, 2002.

53. OZCAN A., ONCU EM., OZCAN AS. Kinetics, isotherm and thermodynamic studies of adsorption of acid blue from aqueous solution onto neutral Sepiolite. Colloid Surf., A193, 90, 2006.

54. SUYAMBOO BK., PERUMAL RS. Equilibrium, thermodynamic and kinetic studies on adsorption of a Basic Dye by Citrullus Lanatus Rind. Iranica J. Energy and Environ., 3, 23-34, 2012.

55. GRELUK M., HUBICKI Z. Kinetics, isotherm and thermodynamic studies of Reactive Black 5 removal by acid acrylic resins. Chem. Eng. J., 162, (3), 919, 2010.

56. KARADAG D., TURAN M., AKGUL E., TOK S., FAKI A. Adsorption equilibrium and kinetics of Reactive Black 5 and Reactive Red 239 in aqueous solution onto surfactant-modified zeolite. J. Chem. Eng. Data, 52, 1615, 2007.

57. AKSU Z., TATLI AI., TUNC O. A comparative adsorption/biosorption study of Acid Blue 161: effect of temperature on equilibrium and kinetic parameters. Chem. Eng. J., 142, 23, 2008.

58. BAYRAMOGLU G., ALTINAS B., ARICA MY. Adsorption kinetics and thermodynamic parameters of cation-exchange resin. Chem. Eng. J., 152, 339, 2009. 